\title{
Effect of Biopriming on Seedling Vigour in Green Gram Var Co 8
}

\author{
N. Subapriya and R. Geetha* \\ Department of Seed Science and Technology, Agricultural College and Research Institute, \\ Madurai, Tamil Nadu Agricultural University, Tamil Nadu, India \\ *Corresponding author
}

\begin{tabular}{|c|}
\hline Keywords \\
\hline $\begin{array}{l}\text { Greengram, } \\
\text { Biopriming, Liquid } \\
\text { biofertilizers, } \\
\text { Vigour }\end{array}$ \\
\hline Article Info \\
\hline $\begin{array}{l}\text { Accepted: } \\
04 \text { April } 2019 \\
\text { Available Online: } \\
10 \text { May } 2019\end{array}$ \\
\hline
\end{tabular}

\section{Introduction}

Greengram is the third important pulse crop in India, covering an area of 2.86 million hectares, accounting for 12 per cent of the total acreage, but constitutes only 8 per cent of the total pulse production of the country. In Tamil Nadu it occupies $4.97 \%$ (1.71 lakh ha) of area, $4.58 \% \quad(0.55$ lakh tonners $)$ production, and productivity of $321.64 \mathrm{~kg} / \mathrm{ha}$. It is rich in quality protein, minerals and vitamins, so they are considered as inseparable ingredients in the diets of a vast majority of Indian population.

Greengram var $\mathrm{CO} 8$ is one of the newly released short duration crop with determinate plant type expressing synchronized maturity, suitable for mechanical harvest. It is resistant to yellow mosaic virus, stem necrosis and moderately resistant to root rot. It is also moderately resistant to aphids and stem fly.

Greengram is raised as rainfed crop in many parts of Tamil Nadu. Maintaining the plant population in the field is one of the easiest way to expect maximum productivity under rainfed situations. Presowing treatments pays way for the better emergence under these situations.

Seed priming is a controlled hydration process that involves exposing seeds to low water potentials that restrict germination, but 
permits pregerminative physiological and biochemical changes (Khan, 1992). Seed priming increases the rate and uniformity of emergence and crop establishment (Karthika and Vanangamudi, 2013). Priming with microbes expresses added advantage, as they secrete plant growth promoters (auxins, abscisic acid, gibberellic acid, cytokines, and ethylene) and enhance seed emergence and root growth (Santner et al., 2009). It not only improves the seed germination but also helps in the spread of microbes in root rhizosphere. Hence the present study was designed to investigate the beneficial effects of biopriming on greengram using liquid biofertlizers.

\section{Materials and Methods}

The studies were carried out at Department of Seed Science and Technology, Agricultural College and Research Institute, Tamil Nadu Agricultural University, Madurai. Genetically pure seeds of greengram var. CO 8 graded using $8 \times 8 \mathrm{~mm}$ sieve formed the base material for this study. Fresh seeds of greengram $\mathrm{CO} 8$ having the initial germination of $85 \%$ were imposed with priming using liquid biopriming agents viz. Rhizobium, Phosphobacteria and Pseudomonas at different concentrations of 1, 2 and 5 per cent and seeds were soaked in double the volume of solutions forl hour followed by slow moistening in gunny for 2 hours. Hydropriming was also attempted. After priming, the seeds were shade dried and again sun dried to the original moisture content and subjected to germination test (ISTA 1999). The unprimed seeds served as control. Seeds were evaluated for germination (ISTA 1999), shoot length (cm), root length (cm), dry matter production per 10 seedlings (g), speed of germination (Maguire 1962) and vigour index values (Abdul-Baki and Anderson 1973). The experiment was carried out with three replications in factorial completely randomized block design. The data obtained from different experiments were analysed for the ' $F$ ' test of significance following the methods described by Panse and Sukhatme (1985).

\section{Results and Discussion}

Statistically significant variations were observed for all the parameters studied due to priming treatments and its concentration of biopriming. The speed of germination, germination, root and shoot length, dry matter production and vigour index were significantly influenced by biopriming treatment, concentrations of biopriming and their interactions.

The rate of germination was higher for the bioprimed seeds compared to hydropriming or untreated control irrespective of concentrations of the solutions (Fig. 1). The seed germination percentage was also higher with bioprimed seeds, among the biopriming agents rhizobium outperformed others, recorded $95 \%$ germination compared to control $(85 \%)$ or hydroprimed seeds $(88 \%)$. Among the priming concentrations, 5\% recorded higher germination followed by $2 \%$ and $1 \%$ (Table 1). From the interactions, it was observed that biopriming with rhizobium at $5 \%$ recorded the highest germination percentage (99\%) This may due to synthesis of Auxin, gibberellin and cytokinin, when the seeds were inoculated with Rhizobium. Similar results were observed by Morgenstern and Okon (1987).

The rate of germination reflected on the growth of the seedling and the highest shoot length was recorded with bioprimed seeds of which rhizobium $(21.76 \mathrm{~cm})$ treated seeds surpassed others. The second best was phosphobacteria $(20.60 \mathrm{~cm})$ and next best was Pseudomonas $(20.33 \mathrm{~cm})$. The increased concentration of the priming solution always 
had its impact on the seedling growth and 5\% recorded the highest shoot length followed by $2 \%$ and $1 \%$ (Fig. 2). The interactions effects showed that biopriming with rhizobium at 5\% $(22.08 \mathrm{~cm})$ recorded the highest shoot length than others. This may be due to auxins, positively influences gibberellin that promotes cell elongation, thus increased seedling length (Fayez et al., 1985).

The seedlings raised from the bioprimed seeds expressed longer root length especially in rhizobium $(16.73 \mathrm{~cm})$ treated seeds followed by phosphobacteria $(16.03 \mathrm{~cm})$ and Pseudomonas $(15.08 \mathrm{~cm})$. Among the priming concentrations 5\% recorded the highest root length followed by $2 \%$ and $1 \%$ (Fig. 2). In comparison with the interactions, it was revealed that seed inoculation with rhizobium at $5 \%$ produced the highest root length (17.15 $\mathrm{cm})$.

This root enhancing effect is due to the production of phytohormone especially IAA which promote a number of plant functions (Chasan, 1993; Key, 1989; Sach, 1993; Warren Wilson, 1993). Seed inoculation with Rhizobium promotes early seedling root growthin non-legumes too which stimulates the phytohormone production (Noel et al., 1996).

Table.1 Effect of seed biopriming with different liquid culture on germination (\%) and vigour index I in green gram var. $\mathrm{CO} 8$

\begin{tabular}{|c|c|c|c|c|c|c|c|c|}
\hline \multirow{3}{*}{$\begin{array}{c}\text { PRIMING } \\
\text { TREATMENT } \\
\text { (P) }\end{array}$} & \multicolumn{4}{|c|}{ GERMINATION (\%) } & \multicolumn{4}{|c|}{ VIGOUR INDEX II } \\
\hline & \multicolumn{3}{|c|}{$\begin{array}{l}\text { CONCENTRATIONS } \\
\text { (C) }\end{array}$} & \multirow[t]{2}{*}{ MEAN } & \multicolumn{3}{|c|}{$\begin{array}{l}\text { CONCENTRATIONS } \\
\text { (C) }\end{array}$} & \multirow[t]{2}{*}{ MEAN } \\
\hline & $1 \%$ & $2 \%$ & $5 \%$ & & $1 \%$ & $2 \%$ & $5 \%$ & \\
\hline Rhizobium & $\begin{array}{c}91 \\
(72.29)\end{array}$ & $\begin{array}{c}96 \\
(78.46)\end{array}$ & $\begin{array}{c}99 \\
(85.87)\end{array}$ & $\begin{array}{c}95 \\
(78.87)\end{array}$ & 14.51 & 16.00 & 18.43 & 16.31 \\
\hline Phosphobacteria & $\begin{array}{c}88 \\
(69.73)\end{array}$ & $\begin{array}{c}91 \\
(72.29)\end{array}$ & $\begin{array}{c}95 \\
(76.83)\end{array}$ & $\begin{array}{c}91 \\
(72.95)\end{array}$ & 13.79 & 14.51 & 16.09 & 14.80 \\
\hline Pseudomonas & $\begin{array}{c}84 \\
(66.53)\end{array}$ & $\begin{array}{c}89 \\
(71.01)\end{array}$ & $\begin{array}{c}92 \\
(73.57)\end{array}$ & $\begin{array}{c}88 \\
(70.37)\end{array}$ & 13.44 & 14.00 & 15.03 & 14.15 \\
\hline Hydropriming & $\begin{array}{c}88 \\
(69.73)\end{array}$ & $\begin{array}{c}88 \\
(69.73)\end{array}$ & $\begin{array}{c}88 \\
(69.73)\end{array}$ & $\begin{array}{c}88 \\
(69.73)\end{array}$ & 13.49 & 13.49 & 13.49 & 13.49 \\
\hline Control & $\begin{array}{c}85 \\
(67.52)\end{array}$ & $\begin{array}{c}85 \\
(67.52)\end{array}$ & $\begin{array}{c}85 \\
(67.52)\end{array}$ & $\begin{array}{c}85 \\
(67.52)\end{array}$ & 13.36 & 13.36 & 13.36 & 13.36 \\
\hline \multirow[t]{2}{*}{ MEAN } & $\begin{array}{c}87 \\
(69.16)\end{array}$ & $\begin{array}{c}90 \\
(71.80)\end{array}$ & $\begin{array}{c}92 \\
(74.70)\end{array}$ & $\begin{array}{c}89 \\
(70.63)\end{array}$ & 13.72 & 14.27 & 15.28 & 14.42 \\
\hline & $\mathrm{P}$ & $\mathrm{C}$ & \multicolumn{2}{|c|}{ PXC } & $\mathrm{P}$ & $\mathrm{C}$ & \multicolumn{2}{|c|}{ PXC } \\
\hline S. Ed & 1.12 & 0.86 & \multicolumn{2}{|c|}{1.94} & 0.27 & 0.21 & \multicolumn{2}{|c|}{0.47} \\
\hline $\mathrm{CD}(0.05)$ & 2.29 & 1.77 & \multicolumn{2}{|c|}{3.96} & 0.56 & 0.43 & \multicolumn{2}{|c|}{0.97} \\
\hline
\end{tabular}


Fig.1 Effect of seed biopriming with different liquid culture on seedling length $(\mathrm{cm})$ and vigour index I in green gram var. CO 8

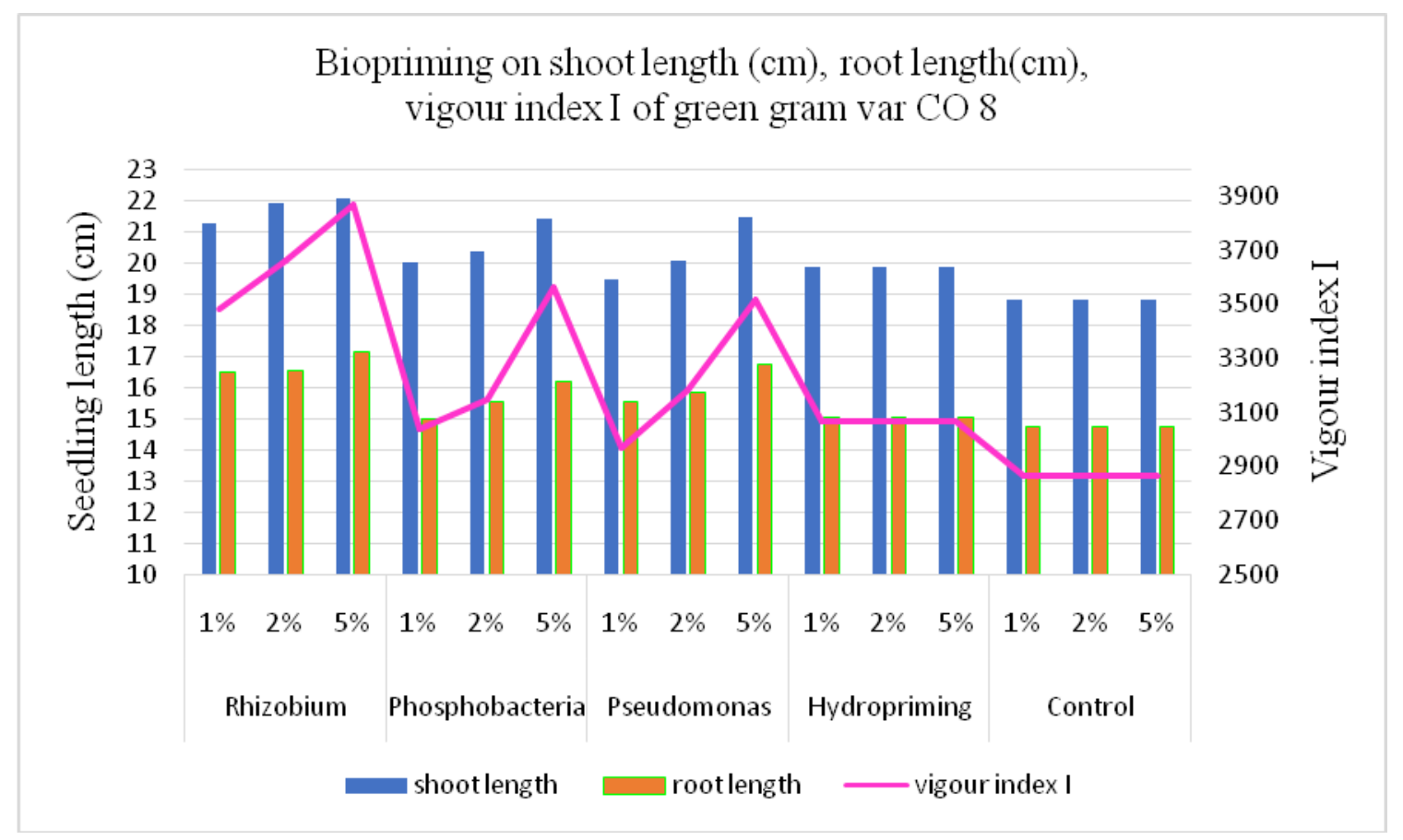

Fig.2 Effect of seed biopriming with different liquid culture on speed of germination and dry matter production ( $\mathrm{mg} / \mathrm{seedlings)} \mathrm{in} \mathrm{green} \mathrm{gram} \mathrm{var.} \mathrm{CO} 8$

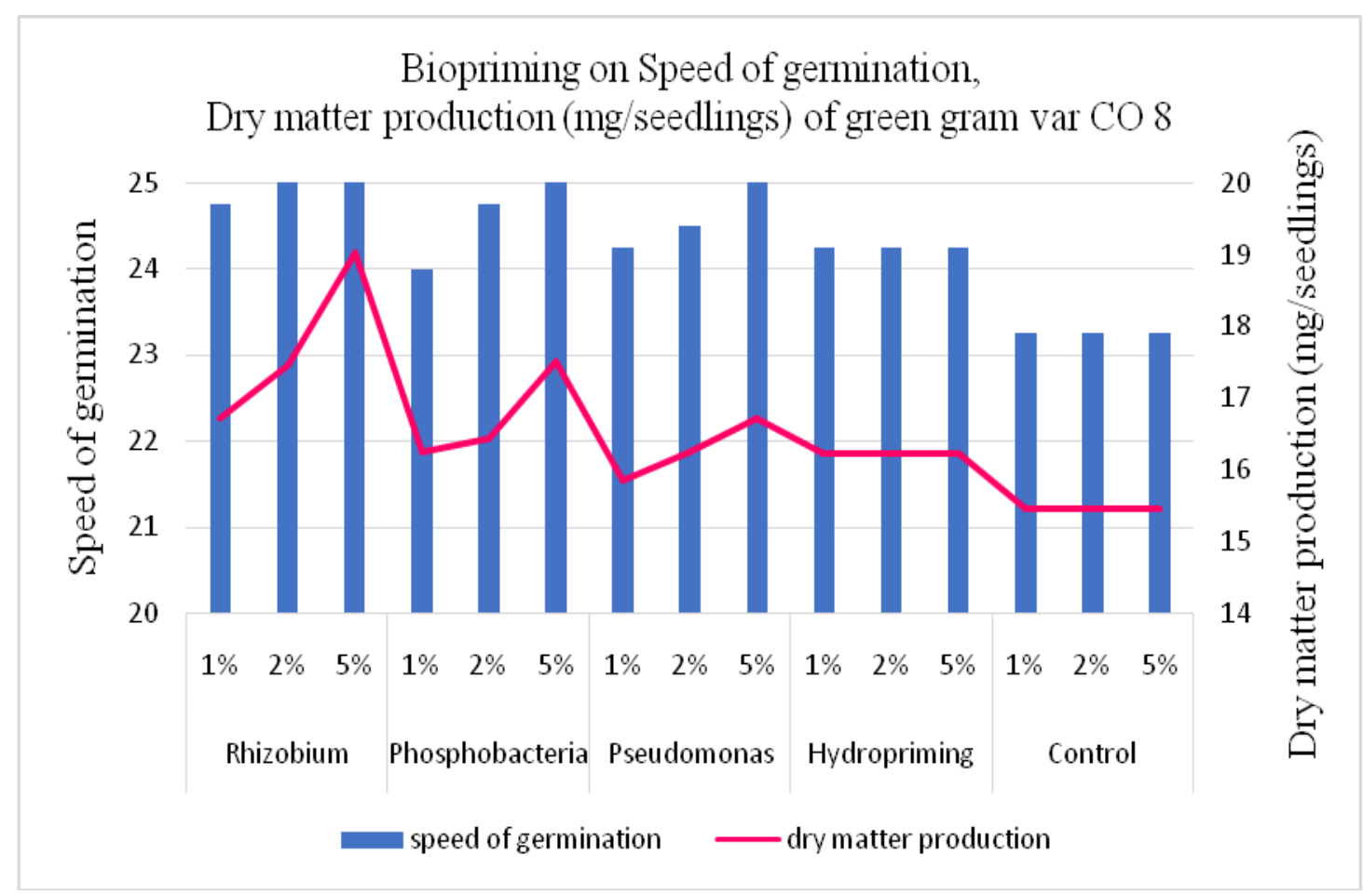


Fig.3 Speed of germination at 48 hrs of germination as influenced by rhizobium biopriming

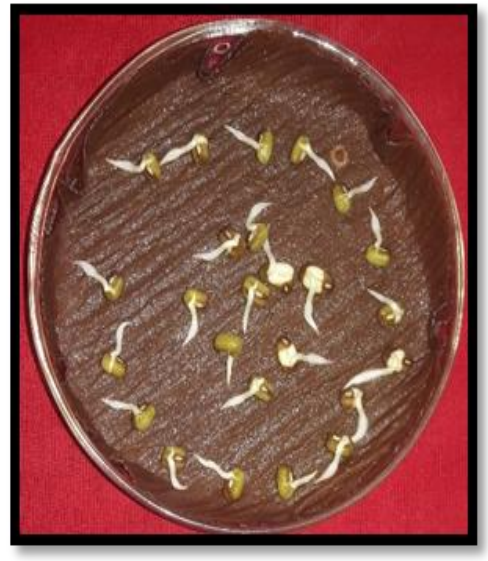

NON PRIMED SEED

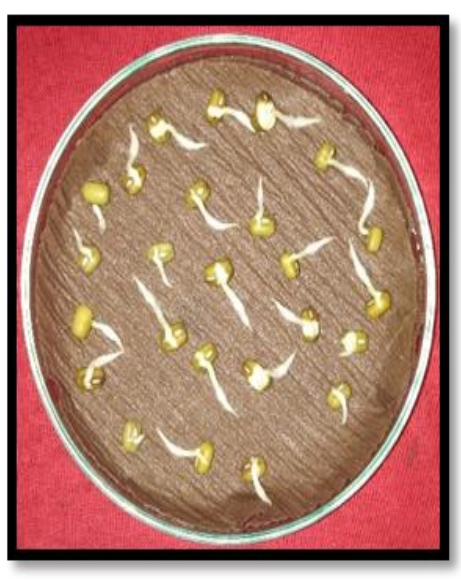

HYDROPRIMING

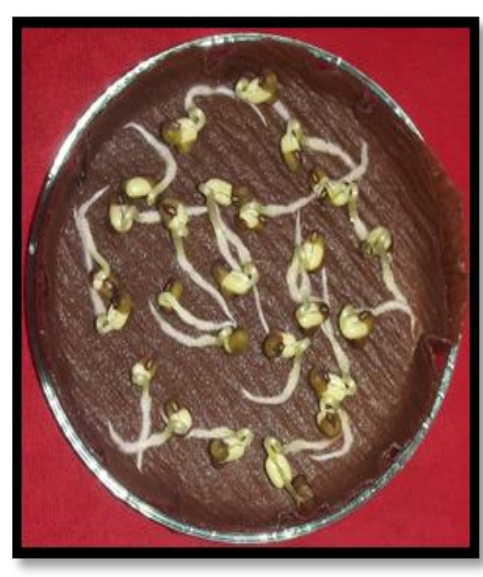

SEED BIOPRIMED WITH RHIZOBIUM 5\%

Fig.4 Seedling vigour at 7 th day of germination as influenced by rhizobium biopriming

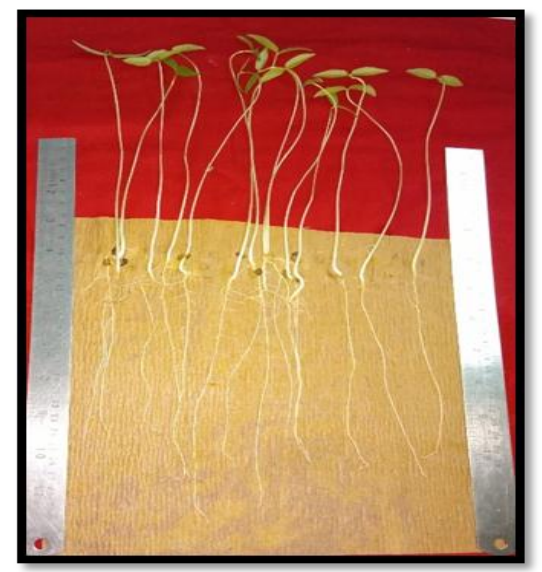

NON PRIMED SEED

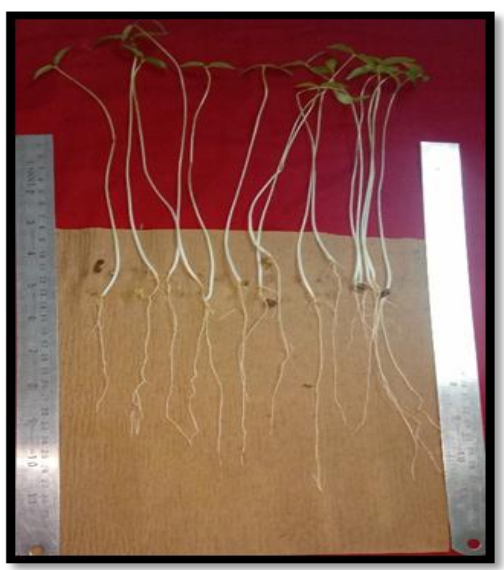

HYDROPRIMING

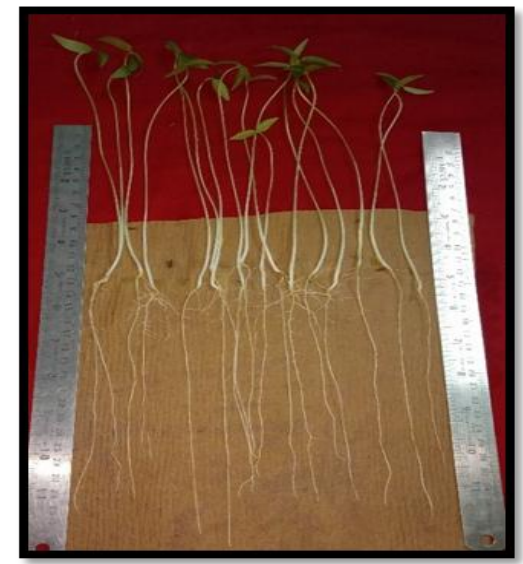

SEED BIOPRIMED WITH RHIZOBIUM 5\%
The improved seedling length due to biofertilizer had an impact on the dry matter production of seedling. The dry weight of seedling were higher by $13 \%$ in case of rhizobium treated seeds and $7 \%$ with phosphobacteria treated seeds and biopriming at $5 \%$ recorded the highest dry matter production followed by $2 \%$ and $1 \%$ (Fig. 2). From the interactions, it was observed that biopriming at rhizobium 5\% (0.1903 g /10 seedlings) recorded higher dry matter production than nonprimed seeds $(0.1545 \mathrm{~g}$ /10 seedlings). Shamsuddin et al., (2000) recorded the greater total dry matter 
accumulation in rice seedling due to inoculation with Bradyrhizobia strain UPMR29 and UPMR48 which trigger plant growth stimulation and vigour of young seedlings.

The increase in seedling growth or dry matter production directly correlates with the vigour index values and both vigour index $I$ and vigour index II recorded the highest values for bioprimed seeds than control or hydroprimed seeds (Fig. 1, 2, 3 and 4). Similar to other parameters rhizobium treatment recorded the highest vigour index I (3661) followed by phosphobacteria (3250) and Pseudomonas (3220). The positive influence of rhizobium on speed of germination and germination \% reproduced more on dry matter production which paves way to attain the highest vigour index II (16.31) followed by phosphobacteria (14.80) and Pseudomonas (14.15). Biswas et al., (2000), reported that rhizobium, can promote growth and vigour of rice seedlings, and this benefit the early seedling development and increased grain yield at maturity.

Therefore, overall it may be concluded that green gram seeds could be bioprimed with rhizobium at $5 \%$ concentration for better germination and establishment.

\section{References}

Abdul-Baki and Anderson, 1973. Vigour determination in soybean seed by multiple criteria. Crop Science, 13: 630633.

Biswas, et al., 2000. Rhizobial Inoculation Influences Seedling Vigour and Yield of Rice. Agronomy Journal, 92 (5): 880-886.

Chasan, R., 1993. Embryogenesis: New molecular insights. Plant Cell, 5: $597-$ 599.

Fayez, et al., 1985. The possible use of nitrogen fixing Azospirilum as biofertilizer for wheat plants. Egypt. J. Microbiol., 20(2), 199-206.

ISTA. 1999. International Rules of Seed Testing. Seed Science and Technology, 27: 27-32.

Karthika and Vanangamudi, K. 2013. Biopriming of maize hybrid $\mathrm{COH}(\mathrm{M})$ 5 seed with liquid biofertilizers for enhanced germination and vigour. African Journal of Agricultural Research, 8(25): 3310-3317.

Key, J.L., 1989. Modulation of gene expression by auxin. BioEssays, 11: $52-58$

Khan, A.A., 1992. Pre plant physiological seed conditioning. Hort. Rev. 13:131181.

Morgenstern, E., and Okon, Y. 1987. The effect of Azospirillum brasilense and auxin on root morphology in seedlings of Sorghum bicolour $\times$ Sorghum sudanense. Arid Soil Research Rehabilitation 1: 115-127.

Noel, et al., 1996 Rhizobium leguminosarum as a plant growth-promoting rhizobacterium: direct growth promotion of canola and lettuce. Can. J. Microbiol. 42, 279-283.

Panse, V.G., and Sukatme, P.V., 1985. Statistical methods for agricultural workers. ICAR Publication, New Delhi. pp 359. Rice W A and Olsen P E. 1992. Effect of inoculation method and size of Rhizobium meliloti population in the soil on nodulation of alfalfa. Canadian Journal of Soil Science, 72: 57-67.

Sachs, T., 1993. The role of auxin in the polar organization of apical meristems. Aust. J. Plant Physiol., 20: 531-533.

Santner, et al., 2009. Plant hormones are versatile chemical regulators of plant growth. Nature Chem. Biol.; 5: 301307.

Shamsuddi, et al., 2009. The effect of 
rhizobacterial inoculation on growth and nutrient accumulation of tissuecultured banana plantlets under low Nfertilizer regime. Afr. J. Biotechnol., 8: 5855-5866.
Warren-Wilson, J., and P.M. Warren-Wilson, 1993. Mechanisms of auxin regulation of structural and physiologic polarity in plants, tissues, cells and embryos. Aust. J. Plant Physiol., 20: 555-571.

\section{How to cite this article:}

Subapriya, N. and Geetha, R. 2019. Effect of Biopriming on Seedling Vigour in Green Gram Var Co 8. Int.J.Curr.Microbiol.App.Sci. 8(05): 51-57. doi: https://doi.org/10.20546/ijcmas.2019.805.007 